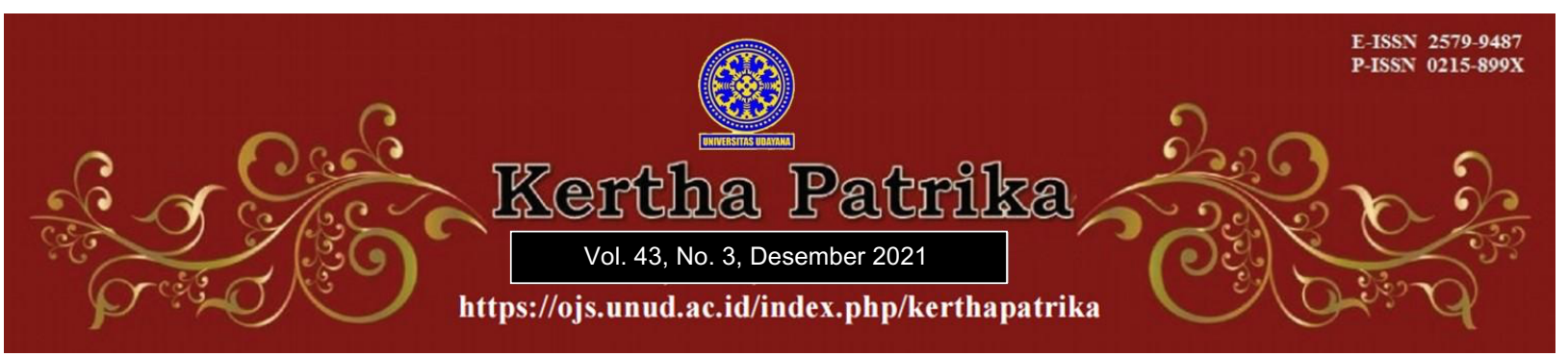

\title{
Potret Kriminologis Korupsi di Lembaga Pemasyarakatan Sukamiskin dan Pencegahannya: Perspektif Sobural

\author{
Hwian Christianto ${ }^{1}$
}

${ }^{1}$ Fakultas Hukum Universitas Surabaya, E-mail: $\underline{\text { hw_christianto@staff.ubaya.ac.id }}$

\begin{tabular}{l}
\hline Info Artikel \\
\hline Masuk: 19 Mei 2020 \\
Diterima: 11 Desember 2021 \\
Terbit: 28 Desember 2021 \\
Keywords : \\
Sobural, Corruption, Correctional \\
Facility, Criminology \\
\\
\\
\\
10.24843/KP.2021.v43.i03.p06 \\
Corresponding Author: \\
Hwian Christianto, \\
hw_christianto@staff.ubaya.ac.id \\
Kata kunci: \\
Pobural, Korupsi, Lembaga \\
Pemasyarakatan, Kriminologi \\
\end{tabular}

\begin{abstract}
Correctional facilities turn out to be a place for corruption by perpetrators, both by the wardens and prisoners. Law enforcement was then considered to have failed to maintain public trust in providing penitentiary treatment through imprisonment for inmates because they have become increasingly skilled in corruption during their time in the correctional facilities. The discussion of the root causes of corruption in prisons is very interesting in terms of the approach to social, cultural values, and structural factors. Two main problems that will be discussed in this article are related to (1) the importance of the sobural approach in corrupt practices in penitentiaries in Indonesia and (2) how the sobural approach can be applied to corruption prevention efforts in penitentiaries. A juridical-normative research method was conducted to analyze the two issues by combining legal arrangements related to corruption cases that have occurred in penitentiaries. The result showed that Sobural Approach presents an understanding of corruption not only as an act that violates legal provisions, but also as an act that arises because it is supported by social, cultural, and structural factors of the perpetrators and society that have not been well-formed. A comprehensive understanding of corruption in penitentiaries provides an evaluative note of effective corruption prevention efforts.
\end{abstract}

\footnotetext{
Abstrak

Lembaga Ppemasyarakatan ternyata menjadi tempat untuk melakukan korupsi oleh pelaku baik oleh petugas lembaga tersebut maupun narapidana. Penegakan Hukum pun dinilai gagal menjaga kepercayaaan masyarakat untuk memberikan pembinaan melalui sanksi penjara bagi narapidana karena mereka justru menjadi semakin ahli dalam melakukan korupsi ketika berada di lembaga pemasyarakatan. Pembahasan akar masalah korupsi dalam Lembaga Pemasyarakatan sangat menarik ditinjau dari pendekatan faktor sosial, nilai budaya dan faktor struktural. Dua rumusan masalah yang akan dibahas dalam artikel ini berkaitan dengan (1) Arti penting pendekatan sobural dalam praktik korupsi di Lembaga Pemasyarakatan di Indonesia serta (2) Bagaimana pendekatan sobural dapat diterapkan dalam upaya pencegahan korupsi di Lembaga Pemasyarakatan. Metode penelitian yuridis
} 


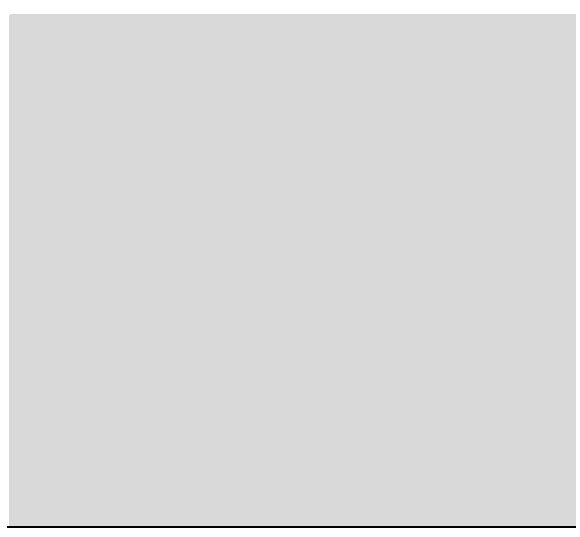

\begin{abstract}
normatif digunakan untuk menganalisis kedua permasalahan dengan memadukan pengaturan hukum terkait dengan perkara pidana korupsi di Lembaga Pemasyarakatan yang pernah terjadi. Hasil penelitian menunjukkan pendekatan Sobural menyajikan pemahaman korupsi tidak hanya sebagai sebuah perbuatan yang melanggar ketentuan hukum, akan tetapi juga sebagai perbuatan yang muncul karena didukung nilai sosial, budaya dan faktor struktural pelaku dan masyarakatyang belum terbentuk dengan baik. Pemahaman menyeluruh atas korupsi di Lembaga Pemasyarakatan memberikan catatan evaluatif terhadap upaya pencegahan korupsi yang efektif.
\end{abstract}

\title{
1. Pendahuluan
}

Kasus korupsi yang melibatkan petugas Lembaga Pemasyarakatan (Lapas) Sukamiskin bukanlah kasus korupsi pertama. Sebelumnya terdapat 3 (tiga) kasus yang melibatkan petugas Lembaga Pemasyarakatan dan dilakukan oleh narapidana kasus korupsi. Kasus penyediaan fasilitas sel tahanan mewah lengkap dengan perabotan pada narapidana Artalyta Suryani yang menyupa jakasa Urip Tri Gunawan di Rumah Tahanan Wanita Pondok Bambum Jakarta Timur. Begitu pula penyediaan fasilitas sel tahanan mewah narapidana kasus tindak pidana pencucian uang, Haryanto Chandra di Lapas Cipinang serta sel tahanan mewah narapidana kasus tindak pidana narkotika, Agusrin Najamuddin di Lapas Sukamiskin. ${ }^{1}$ Jika diperhatikan di antara ketiga kasus tersebut, memang hanya kasus pertama yang melibatkan narapidana kasus korupsi. Akan tetapi ketiganya sama-sama menunjukkan adanya tindak pidana suap pada petugas Lapas. Hasil jajak pendapat yang dilakukan Litbang Kompas ${ }^{2}$ pada 668 responden pun menunjukkan bahwa masyarakat sangat yakin terjadinya kasus suap antara petugas Lapas dan narapidana $(90,4 \%, n=604$ orang) yang disebabkan lebih banyak karena Sistem Pengawasan yang lemah $(33,7 \%, n=225$ orang), Narapidana Korupsi masih memiliki uang banyak (32,9\%, n=220 orang) serta Fasilitas Penjara yang buruk $(15,4 \%$, $\mathrm{n}=103)$.

Korupsi pada dasarnya merupakan hal yang sangat berbahaya dan merugikan keuangan negara. Saldi Isra, et.al. ${ }^{3}$ menegaskan korupsi memiliki sifat destruktif dari sisi keuangan negara/perekonomian megara akan tetapi menciderai kepercayaan masyarakat. Terlebih kasus korupsi yang melibatkan petugas Lapas Sukamiskin. Kasus korupsi yang melibatkan petugas Lapas Sukamiskin menjadi hal yang menarik untuk dikaji lebih lanjut jika dilihat dari sisi pelaku, tempat serta kondisi dilakukannya perbuatan korupsi. Pelaku dalam kasus korupsi merupakan mantan Kepala Lapas Sukamiskin yang secara yuridis normatif memegang jabatan pemerintahan sebagai penegak hukum. Locus delicti perbuatan di Lapas Sukamiskin yang seharusnya menjadi tempat pemasyarakatan justru disalahgunakan untuk melakukan perbuatan yang dilarang. Kondisi dilakukannya perbuatan justru dilakukan pada saat pelaku memiliki kewenangan untuk melakukan pengelolaan Lapas khusus narapidana perkara korupsi. Pelaku memberikan fasilitas penjara mewah dan izin keluar Lapas kepada narapidana yang memiliki harta kekayaan.

Litbang Kompas, “Budaya Suap Mencengkeram Lapas”, Harian Kompas 30 Juli 2018, hlm.4 Ibid

3 Isra, Saldi et.al.(2017). Obstruction of Justice in the Effort to Eradicate Corruption in Indonesia. Internasional Journal of Law Crime and Justice, 72-83. doi: 10.1016/j.ijlcj.2017.07.001. p.72. 
Dua hal pertama dalam kasus tersebut sebenarnya cukup dikaji berdasarkan ketentuan hukum pidana yang berlaku. Kajian terhadap perkara korupsi yang melibatkan mantan Kepala Lapas Sukamiskin dari segi yuridis sebenarnya telah diatur dalam UndangUndang khusus. Berdasarkan penafsiran Eksegetikal4 pemahaman akan "korupsi" merujuk pada maksud dari ketentuan hukum terkait. Korupsi menjadi perbuatan yang dilarang berdasarkan Undang-Undang No. 31 Tahun 1999 tentang Pemberantasan Tindak Pidana Korupsi jo Undang-Undang No. 20 Tahun 2001 tentang Perubahan Undang-Undang No. 31 Tahun 1999 (UU PTPK). Secara yuridis normatif, perbuatan korupsi memiliki unsur-unsur perbuatan pidana yang secara tegas dipersyaratkan sebagai batasan perbuatan korupsi (Pasal 2 ayat (1) UUPTPK). Pengenaan ketentuan hukum pidana UUPTPK pada dasarnya memiliki tujuan represif kepada pelaku untuk memberikan hukuman. Hanya saja pemberlakuan Pasal 2 ayat (1) UUPTPK cenderung mengabaikan pemahaman penegak hukum akan kondisi dilakukannya perbuatan oleh pelaku secara kasuistis. Hal yang dimaksudkan menunjuk pada pemahaman kondisi masyarakat dimana pelaku berada memiliki pengaruh kepada pelaku untuk melakukan perbuatan korupsi dalam hal ini suap. Bahwa suatu perbuatan menyalahgunakan kekuasaan yang ada pada dirinya sebagai pejabat pemerintah tetap merupakan perbuatan melawan hukum atas UUPTPK namun tidak menggali kondisi apa yang melatarbelakangi atau memudahkan atau membuat pelaku melakukan perbuatan korupsi.

Terkait dengan penanggulagan tindak pidana korupsi (suap) tersebut pendekatan lain perlu dilakukan untuk mencari sebab dilakukannya kejahatan tersebut secara khusus pendekatan kriminologis. Djanggih \& Qamar ${ }^{5}$ menegaskan pendekatan kriminologis dapat digunakan untuk mendukung efektifitas penanggulangan kejahatan terkait bagaimana dan mengapa pelaky melakukan kejahatan dan faktor non yuridis yang memengaruhinya. Pendekatan kriminologis memiliki peran yang penting dalam memahami sebab kejahatan suap yang dilakukan narapidana kasus korupsi pada petugas Lapas Sukamiskin. Pemahaman akan kejahatan tidak hanya terbatas pada pemahaman perbuatan yang dituduhkan kepada pelaku telah memenuhi unsur perbuatan pidana suatu ketentuan hukum atau sebaliknya. Penggunaan pendekatan Sobural atas perbuatan korupsi di Lapas Sukamiskin akan membantu memberikan pemahaman perbuatan korupsi secara utuh sehingga diperoleh pemahaman utuh akan perbuatan yang dilakukan. Pemahaman yang utuh tersebut menjadi modal berharga bagi upaya pembarantasan korupsi di Lapas demi menaikkan citra Lapas yang masih buruk di mata masyarakat $(80,4 \%, n=537 \text { orang })^{6}$ Berdasarkan pemahaman tersebut, hal utama yang perlu dibahas lebih lanjut yaitu Pertama, arti penting pemberlakuan pendekatan Sobural dalam memahami kejahatan korupsi dan Kedua, Penerapan pendekatan Sobural sebagai upaya Pencegahan dan Pemberantasan Korupsi di Lapas.

\section{Metodologi Penelitian}

4 Susanti, Dyah Octorina \& Efendi A.(2019). Memahami Teks Undang-Undang dengan Metode Interpretasi Eksegetikal. Jurnal Kertha Patrika, 41(2), 141-154. doi: 10.24843/KP.2019.v41.i02.p0 5, p. 151

5 Djanggih, H., \& Qamar, N. (2018). Penerapan Teori-Teori Kriminologi dalam Penanggulangan Kejahatan Siber (Cyber Crime). Pandecta Research Law Journal, 13(1), 10-23. doi: 10.15294/pandecta.v13i1.14020, p. 11

6 Litbang Kompas, Loc.Cit. 
Metodologi penelitian menggunakan metode yuridis normatif yang mendasarkan diri pada data primer berupa peraturan perundang-undangan yang mengatur tentang Lembaga Pemasyarakatan dan Tindak Pidana Korupsi, yaitu Undang-Undang 12 Tahun 1995 tentang Lembaga Pemasyarakatan dan Undang-Undang No. 31 Tahun 1999 tentang Pemberantasan Tindak Pidana Korupsi jo Undang-Undang No. 20 Tahun 2001 tentang Perubahan Undang-Undang No. 31 Tahun 1999 (UU PTPK). Pemahaman ketentuan yuridis normatif dari kedua undang-undang tersebut dibandingkan dengan pemahaman konsep tindak pidana korupsi dari sisi kriminologi, teori Nilai Sosial, Aspek Budaya dan Faktor Struktural (Sobural). Kajian kriminologis dengan teori Sobural tersebut dikaitkan dengan studi kasus yang pernah terjadi di Lembaga Pemasyarakatan Sukamiskin. Hasil di analisis lebih lanjut untuk menemukan kaitan erat antara nilai sosial, aspek budaya dan faktor struktural memengaruhi terjadinya tindak pidana suap di Lembaga Pemasyarakatan Sukamiskin.

\section{Hasil Dan Pembahasan}

\subsection{Sobural sebagai Pendekatan Kriminologis}

Pendekatan Sobural merupakan upaya pemahaman kejahatan yang terjadi berdasarkan situasi dan kondisi dimana perbuatan itu dilakukan. Jacob Elfinus Sahetapy (J. E. Sahetapy) memperkenalkan pemahaman kejahatan itu harus dilakukan sesuai dengan memahami situasi dan kondisi masyarakat Indonesia. J.E. Sahetapy menolak penggunaan teori Kriminologi tanpa melibatkan situasi dan kondisi masyarakaat Indonesia. 7 Pemikiran J.E. Sahetapy menegaskan ciri keindonesiaan dalam pemahaman kriminologi atas kasus yang terjadi di Indonesia bukan dengan menggunakan teori Kriminologi asing yang belum tentu cocok diterapkan di Indonesia. Hal tersebut disebabkan karena penilaian akan perbuatan apa yang dinilai sebagai kejahatan tidaklah sama antara satu masyarakat dengan masyarakat lainnya bahkan negara dengan negara lainnya. ${ }^{8}$ Boleh dikatakan Pendekatan Sobural ingin menyajikan ruang gerak bagi pemahaman kejahatan tidak hanya terpaku pada perbuatan akan tetapi faktor apa saja yang memengaruhi perbuatan itu dilakukan.

Pemahaman akan Sobural sebagai sebuah pemikiran Kriminologi sebenarnya sangat menarik jika dikaji lebih lanjut kedudukannya sebagai sebuah teori atau pendekatan dalam Kriminologi. Gardner" menegaskan pemahaman "theory" dalam "theory of law" sebagai "the legal premise or set principles on which a case rests." Berbeda dengan 'pendekatan' (approach) sebagai "proses atau cara memahami sesuatu"10 ia lebih berfungsi sebagai alat atau metode untuk menguraikan sesuatu masalah. Penulis sendiri lebih berargumentasi bahwa Sobural merupakan sebuah pendekatan dalam memahami kejahatan. Hal tersebut didasarkan pada beberapa argumentasi, Pertama, pengenalan Sobural sendiri oleh J.E. Sahetapy merupakan bagian dari upaya untuk 'menganalisa'

7 Sahetapy J.E. (1983). Pisau Analisa Kriminologi: Pidato Pengukuhan Guru Besar Fakultas Hukum Universitas Airlangga, 30 Juli 1983, Surabaya: Fakultas Hukum Universitas Airlangga, p. 3 (Sahetapy, J.E. I)

8 Sahetapy, J.E., Sahetapy, Elfina L. ed.(2005) Pisau Analisis Kriminologi. Bandung: Citra Aditya Bhakti, p. 3 (Sahetapy, J.E. II)

9 Garner, Bryan A. (2004). Black's Law Dictinionary, Eighth Edition, London: West Thomson, p. 1517.

10 Departemen Pendidikan Nasional, Op.cit., p. 306 
causa kejahatan berdasarkan situasi dan kondisi masyarakat Indonesia. ${ }^{11}$ Kedua, Sobural digunakan untuk memahami suatu perbuatan yang disebut sebagai kejahatan baik dari sisi nilai sosial, nilai budaya dan faktor struktural yang diberlakukan di suatu masyarakat. Artinya, Sobural bukanlah suatu prinsip yang digunakan untuk menyelesaikan suatu permasalahan atau kasus. Sobural justru berperan dalam mendeskripsikan secara utuh suatu perbuatan yang dianggap jahat dari tiga kacamata nilai yang memengaruhinya. Hal ini bersesuaian dengan pemahaman civil law yang menegaskan kontribusi penting dari nilai agama dan adat masyarakat ${ }^{12}$ dalam menilai suatu perbuatan. Sebagai contoh, agama Islam sendiri menegaskan landasan pencegahan korupsi sesuai Al-quran Surat Al-Tahrim ayat 6 sedangkan bagi pengemban jabatan sesuai dengan prinsip amanah dalam Q.S. Al-Nisâ [4]: 58. ${ }^{13}$ Berdasarkan hal tersebut, Sobural berperan secara kasuistis tidak dapat menjadi pedoman yang sama sebagaimana layaknya suatu prinsip atau teori. Ketiga, timbulnya pemikiran Sobural dan perkembangan pemikiran selanjutnya tidak pernah ditegaskan sebagai suatu aliran pemikiran tertentu seperti aliran Spiritualisme atau aliran naturalisme. Kedua aliran tersebut memiliki konsep berpikir utama bahwa kejahatan yang terjadi merupakan akibat dari bisikan setan atau secara alami tampak dalam diri manusia. ${ }^{14}$ Sobural justru tidak berfokus pada diri pelaku sebagai obyek kajian utama akan tetapi memahami pula konteks masyarakat dimana pelaku melakukan perbuatan tersebut. Bagi J.E. Sahetapy ${ }^{15}$, Sobural menegaskan bahwa kejahatan merupakan abstraksi mental dari pelaku yang tidak dapat dilepaskan dari konteks masyarakat.

Sebagai sebuah pendekatan Sobural meletakkan jangkar pemahaman kejahatan atas pemberlakuan nilai sosial, nilai budaya dan faktor struktural. Pokok pikiran awal Sobural berada pada pemahaman bahwa "manusia tidak hidu dalam kekosongan. Ia akan bergerak dalam suatu skala...". ${ }^{16}$ Tiap manusia sebagai individu memiliki ruang sosial tempat ia hidup dan menghidupi suatu skala nilai yang dianggap penting. Individu memiliki peran menyesuaikan diri dengan nilai masyarakat yang diberlakukan. Hanya saja tidak semua individu memiliki pemahaman dan pengakuan yang sama akan nilai yang diberlakukan masyarakat sehingga terjadi penyimpangan atau pelanggaran. Teori Interaksionis memberikan kontribusi dalam pemikiran Sobural dalam menjelaskan peran masyarakat dalam pembentukan nilai tersebut. Bedanya, teori interaksionis lebih berfokus pada tanggungjawab individu yang gagal dalam berinteraksi dengan masyarakat sehingga nilai tidak terpenuhi. Sobural justru memberikan penekanan akan interaksi nilai justru menjadi sebab utama dilakukannya pelanggaran. Dengan kata lain, Sobural tidak mengesampingkan situasi dan kondisi masyarakat yang ikut bertanggungjawab atas dilakukannya pelanggaran.

11 Sahetapy J.E. II, Op.Cit., p. 5-6

12 Aditya, Z. F. (2019). Romantisme Sistem Hukum Di Indonesia: Kajian Atas Konstribusi Hukum Adat Dan Hukum Islam Terhadap Pembangunan Hukum Di Indonesia. Jurnal Rechts Vinding: Media Pembinaan Hukum Nasional, 8(1) 37-54. DOI: http://dx.doi.org/10.33331/rechtsvinding.v8i1.305. p. 46

13 Haryadi, Slamet. (2015). Reinterpretasi Tindak Pidana Korups Suap oleh Penegak Hukum dalam Perspektif Hukum Islam. Jurnal Al-'adalah 12(3), 541-552. doi: 10.24042/adalah.v12i1.233, p. 547-549

14 Santoso, Topo \& Zulfa, Eva Achjani. (2001). Kriminologi. Jakarta: Rajawali Press, p.19-33

15 Sahetapy, J.E. II, Op.Cit., p. 20-21

16 Sahetapy J.E. I, Loc.Cit. 
Sobural memadukan pemahaman teori interaksionis yang hanya berfokus pada pelaku dengan pemberlakuan teori anomie sebagaimana dikemukakan oleh Émile Durkheim. Bagi Durkheim sebagaimana dijelaskan oleh Fonseca, et.al. ${ }^{17}$ suatu perbuatan yang dilakukan oleh seseorang tidak dapat dilepaskan dari proses pemberlakuan nilai oleh masyarakat kepada anggotanya (social cohesion). Ketika seseorang gagal mengikuti nilai tersebut maka masyarakatlah yang harus ditinjau ulang pemahaman nilai yang diberlakukannya.

Lebih lanjut, J.E. Sahetapy menegaskan 3 (tiga) proposisi utama dalam memahami relasi pelaku dan masyarakat atas terjadinya kejahatan, antara lain Pertama, tiap masyarakat Indonesia memiliki nilai dasar, yaitu nilai agama, nilai budaya dan nilai sosial yang saling memengaruhi. Kedua, kepatuhan dalam kontekstualisasi nilai dalam kehidupan masyarakat merupakan hal penting bagi anggota masyarakat. Ketiga, keterikatan individu dalam ikatan sosial justru didasarkan pada pemahaman reflektif atas esensi diri manusia di hadapan Tuhan. ${ }^{18}$ Jika diamati tampak jelas bahwa pendekatan Sobural justru memadukan beberapa teori kriminologi, seperti teori interaksionis dan teori anomie tanpa mengabaikan situasi dan kondisi masyarakat Indonesia. Berdasarkan ketiga proposisi tersebut pendekatan Sobural memahami suatu kejahatan terjadi dipengaruhi oleh nilai sosial, nilai budaya dan faktor struktural. Nilai sosial yang dimaksudkan merupakan skala penilaian akan kehidupan bersama antar anggota masyarakat satu dengan lainnya demi menciptakan ketertiban bersama. Nilai sosial atau nilai kemasyarakatan ini merupakan pedoman dalam bertingkah laku bersumber dari norma yang hidup di masyarakat demi mewujudkan tujuan bersama. Sedangkan nilai budaya dalam pendekatan Sobural dimaknai sebagai hasil akal budi manusia dari berinteraksi dengan masyarakat yang terwujud dalam pedoman perilaku yang mendasar. Jika diamati pemahaman akan nilai sosial dan nilai budaya memiliki kesamaan di satu sisi namun jika diamati pula dengan seksama memiliki perbedaan mendasar. Kesamaan terletak dalam hal sumber dari kedua nilai tersebut dari masyarakat tempat dimana seseorang hidup dan berinteraksi. Masyarakat dalam pendekatan Sobural membentuk sebuah tatanan kehidupan yang ajeg di satu sisi namun di sisi lain juga dinamis sesuai dengan perkembangan kehidupan masyarakat. Budaya merupakan hasil interaksi diri-masyarakat sehingga menciptakan sebuah karya fundamental berupa tatanan nilai dasar suatu masyarakat. Berbeda dengan nilai sosial yang terus menerus mengalami perkembangan mengikuti masyarakat itu sendiri. Faktor ketiga, faktor struktural memberikan pertimbangan akan adanya pengelompokan atau stratifikasi masyarakat dipengaruhi oleh sistem sosial yang bergantung pada status (kedudukan) dan peran seseorang. Faktor terakhir ini menekankan ciri khas situasi dari masyarakat tempat pelaku hidup. Interaksi diantara ketiga hal tersebut sangat berkaitan erat dengan perbuatan seperti apa yang dilakukan seseorang, secara khusus pelaku kejahatan. Relasi diantara ketiga hal tersebut tampak dalam diagram 1 berikut:

Diagram 1. Interaksi Sobural
\begin{tabular}{l|l}
\cline { 2 - 2 } \multicolumn{1}{c|}{} & \\
\hline 17 Fonseca, $x$ avier etai. (2019).
\end{tabular}
17 Fonseca, Xavier et.al.(2019). Social Cohesion revisited: a new definition and characterize it. Journal Innqvation: The European Journal of Social Science Research. 32(2), 231-253. doi: $10.1080 / 13511610.2018 .1497480$, p. 237-239
18 Sahetapy J.E. II, Op.cit., p. 82-84 


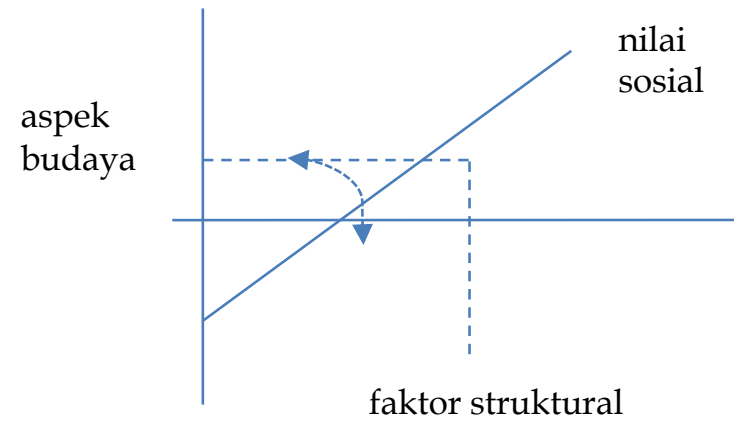

Pendekatan Sobural memperkenalkan adanya kaitan erat antara nilai sosial, aspek budaya dan faktor struktural. Suatu perbuatan ketika dinilai sebagai suatu perbuatan yang merendahkan kemanusiaan, ia akan mendapatkan tekanan dengan pengaruh yang sama dari sistem sosial yang berlaku di masyarakat. Misalnya, A seorang anggota masyarakat melakukan perbuatan yang dinilai melanggar pedoman berperilaku di masyarakatnya, kepadanya mendapatkan tekanan untuk mempertanggungjawabkan perbuatannya dari tokoh masyarakat atau penegak hukum. Hal ini pun dibuktikan Gorsira, et.al. ${ }^{19}$ yang menegaskan kebiasaan masyarakat atau penerimaan masyarakat atas suatu perbuatan yang sebenarnya buruk menjadi hal yang sangat berpengaruh atas terjadinya korupsi. Interaksi antara aspek budaya dan pemberlakuan faktor struktural dalam masyarakat menunjukkan nilai sosal seperti apa yang diberlakukan masyarakat terhadap seseoarang ketika ia melakukan pelanggaran (kejahatan).

Penggunaan Sobural sebagai pendekatan kriminologis atas perbuatan korupsi begitu penting tidak hanya untuk memberikan pemahaman akan sebab dilakukannya korupsi akan tetapi nilai-nilai dan faktor apa yang memengaruhi perbuatan itu dilakukan. Pemahaman akan nilai dan faktor yang memengaruhi seseorang melakukan korupsi di Lapas menjadi pembelajaran penting bagi upaya pemberantasan korupsi baik dari sisi pencegahan maupun penindakan kejahatan korupsi. Terjadinya korupsi di Lapas sebenarnya menjadi tanda adanya ketidaksinambungan nilai sosial dan nilai budaya yang dipahami oleh pelaku atas nilai sosial dan budaya masyarakat. Ia mengalami kegagalan untuk menyesuaikan diri dengan lebih memilih melakukan perbuatan yang bertentangan atau melanggar nilai yang berlaku sebagai akibat pemahaman struktur kekuasaan yang diberlakukan atas dirinya. Pemahaman tersebut menjadi bekal tersendiri bagi upaya pemberantasan korupsi di Lapas secara lebih efektif.

\subsection{Pendekatan Sobural pada Korupsi di Lembaga Pemasyarakatan}

Korupsi di Lembaga Pemasyarakatan dalam pendekatan Sobural harus dikaji berdasarkan pemahaman nilai sosial, nilai budaya dan faktor struktural baik dipahami oleh pelaku maupun masyarakat. Korupsi sebagai kejahatan luarbiasa (extra ordinary crime) dalam konteks masyarakat Indonesia memiliki kompleksitas dari sisi perbuatan

19 Gorsira, Madelijne. Denkers, Adriaan. Huisman, Wim.(2018). Both Sides of the Coin: Motives for Corruption Among Public Officials and Business Employees. Journal of Business Ethics.151, 179-194. doi: 10.1007/s10551-016-3219-2, p. 187 
maupun pembuktian. ${ }^{20}$ UUPTPK menegaskan 'korupsi' sebagai perbuatan yang merugikan keuangan negara atau perekonomian negara dan menghambat permbangunan nasional. Artinya, perbuatan tersebut oleh masyarakat dinilai bertentangan dengan nilai yang diemban oleh bangsa Indonesia sebagaimana tertuang dalam Panacasila dan Undang-Undang Dasar 1945. Nilai kemanusiaan yang adil dan beradab menghendaki perbuatan yang dilakukan oleh manusia sebagai individu sudah selayaknya merupakan bentuk refleksi atas tanggungjawab dirinya di hadapan Tuhan, Sang Pencipta. Soekarno menegaskan bahwa "Kemanusiaan adalah alam manusia ini, de mensheid. Perikemanusiaan adalah jiwa yang merasakan bahwa antara manusia dengan lain manusia adalah hubungannya, jiwa yang hendak mengangkat membedakan jiwa manusia itu lebih tinggi dari jiwa binatang" 21 Kesamaan dalam perikemanusiaan menjauhkan diri dari sikap egoisme yang mementingkan pemuasan diri sendiri ataupun kepentingan kelompok akan tetapi kemanusiaan yang memuliakan kemanusiaan itu sendiri. Di sisi ini penekanan nilai akuntabilitas diri sebagaimana dikemukakan Klitgaard 22 memiliki korelasi. Senada dengan pemahaman tersebut, Othman, Safie \& Hamid ${ }^{23}$ menegaskan peran penting nilai ini sebagai moral impurity tampak dalam tidak adanya integritas diri, keserakahan dan godaan melakukan pelanggaran. Adanya korupsi pada dasarnya tergantung dari akuntabilitas diri yang dalam hal ini tertuju pada nilai kemanusiaan Indonesia. Aktualisasi nilai akuntabilitas inilah yang tampak riil dalam tingkah laku seseorang, secara khusus pelaku korupsi. Seperti ditekankan oleh Prabowo ${ }^{24}$ dan Albanese \& Artello ${ }^{25}$ bahwa pemahaman atas tingkah laku pelaku korupsi inilah membantu pemahaman secara khusus tentang sebab dilakukannya korupsi.

Wang-Sheng Lee \& Guven ${ }^{26}$ dalam penelitiannya menjelaskan adanya pengaruh aspek budaya (cultural values) dari sisi persepsi gender dan preferensi risiko dalam tatanan masyarakat tersebut. Sejalan dengan pemahaman tersebut, Sobural juga menekankan aspek budaya dalam memahami korupsi di Lapas. Aspek budaya Indonesia sebenarnya tidak mengenal perbuatan korupsi sebagai perbuatan yang pantas dilakukan oleh manusia yang beradab. Berbagai pernyataan yang mengungkapkan bahwa korupsi

20 Ifrani.(2017). Tindak Pidana Korupsi sebagai Kejahatan Luar Biasa. Jurnal Al'adl. IX (3), 319336. doi: 10.31602/al-adl.v9i3.1047, p. 323

21 PSP UGM Yogyakarta \& TIFA.(2016). Pancasila sebagai Dasar Negara: Kursus Presiden Soekarno tentang Pancasila. Jakarta: Aditya Media \& Pusat Studi Pancasila (PSP) UGM dan Yayasan TIFA, p. 117

22 U4 Aexpert Answer, "Causes of Corruption in Indonesia", Anti-Corruption Resource Centre, Avalilable from: https://www.u4.no/publications/causes-of-corruption-in-indonesia. (Diakses 19 Mei 2020)

23 Othman, Zaleha. Shafie, Rohami. Fathilatul, Zakimi Abdul. Hamid, (2014). Corruption-Why do they do it? Procedia-Social and Behavioral Studies 164, 248-257. doi:10.1016/j.sbspro.2014.11.074, p. 255

24 Prabowo, Hendi Yogi .(2014). To be corrupt or not to be corrupt: Understanding the behavioral side of corruption in Indonesia. Journal of Money Laundering Control. 17(3), 306-326. doi:10.1108/JMLC-11-2013-0045, p. 313-315

25 Albanese, Jay S. \& Artello, Kristine.(2019). The Behavior of Corruption: An Empirical Typology of Public Corruption by Objectibe \& Method. Criminology, Criminal Justice, Law \& Society. 20(1), 1-12, p. 4-8

26 Lee, Wang-Sheng \& Guven, Cahit. (2013). Enganging in Corruption: The Influence od Cultural Values and Contagion Effects at the Micro Level", Journal of Economic Psychology, 39, 287-300. doi: 10.1016/j.joep.2013.09.006, p. 297-299. 
sudah membudaya27 sebenarnya perlu dikaji lebih lanjut kebenarannya. Myrdal sebagaimana dikutip J.E. Sahetapy ${ }^{28}$ mengungkapkan bahwa korupsi memiliki berbagai macam bentuk yang semuanya telah dikenal sejak adanya pergaulan hidup manusia. Perbuatan korupsi pada dasarnya dilakukan untuk memenuhi keserahakan diri bukan untuk kebutuhan karena jika demikian tidak akan mengabaikan kepentingan orang lain. Telah dikenal oleh masyarakat bukan berarti menjadi budaya sebaliknya korupsi merupakan perbuatan yang dihindari oleh masyarakat. Korupsi dari sisi budaya merendahkan derajat kemanusiaan karena perbuatan tersebut menunjukkan diri pelaku sebagai terutama dari semua manusia yang ada. Bahkan ia mengambil hak ekonomi berupa kesejahteraaan seluruh masyarakat akibat perbuatannya. Catatan menarik diberikan Bernardi \& Hayashi ${ }^{29}$ memiliki kecenderungan untuk memberikan hadiah atau pemberian kepada seseorang dengan alasan mempererat relasi padahal rentan disalahgunakan sebagai hal yang positif.

Sistim nilai Pancasila yang diemban sebagai sistim budaya bangsa Indonesia sama sekali tidak mengenal korupsi sebagai perbuatan yang dianggap baik dalam menjalankan pemenuhan kehidupan. Terkait dengan korupsi yang dilakukan di Lapas Sukamiskin jika ditinjau dari kondisi yang ada merupakan perbuatan suap dimungkinkan terjadi di Lapas lainnya. Gumerov et.al. ${ }^{30}$ menjelaskan secara khusu tentang tindakan "suap" sebenarnya merupakan bentuk korupsi yang sudah dikenal lama oleh masyarakat dimana-mana. Wardhani, Hartati dan Rahmasari ${ }^{31}$ mencatat sebuah temuan adanya sikap tolerir terhadap pemberian suka rela biaya pemberkasan dari Narapidana kepada Walipermasayarakatan akibat kekurangan dana yang dimiliki oleh Pengelola Lapas. Akhirnya kondisi tersebut terus berulang dengan batasan Wali Pemasyarakatan dilarang keras meminta, kecuali pemberian dengan sukarela. Potensi suap ${ }^{32}$ pun muncul dari adanya permintaan suap dan penawaran suap yang dilakukan oleh narapidana dan Wali Pemasyarakatan. Kebiasaan yang terus-menerus dilakukan tersebut tentu tidak dapat dikatakan sebagai budaya karena hanya menonjolkan kepentingan diri narapidana dan petugas Lapas serta kondisi yang bersifat insidentil. Apabila kondisi tersebut terus dibiarkan dan pemberian uang menjadi hal yang dimaklumkan, perbuatan tersebut menjadi perilaku korupsi yang sangat berbahaya.

27 Henderson, J.Vernon \& Kuncoro, Ari. (2011). Corruption and Local Democratization in Indonesia: the Role of Islamic Parties. Journal Development Economics. 94(2), 164-180. doi: 10.1016/j.jdeveco.2010.01.007, p. 164 .

28 Sahetapy, J.E. II, Loc.Cit.

29 R. Black, "Asian Etiquette", November 11 sebagaimana dikutip oleh Richard A. Bernardi \& Ikki Hayashi. (2013).The Association between Bribery and Unethical Actions: An Asian Perspective. European Journal of Business and Innovation Research. 1(2), 70-84. p. 73-74.

30 Gumerov, A. Timur, et. al. (2016). Concept and Criminological Characteristics of Corruption on Criminality. Journal of Legal, Ethical dan Regulatory Issues, 19 (Special Issues), 82-87. p. 85-87.

31 Wardhani, Noeke Sri. Hartati, Sri \& Rahmasari, Helda.(2015). Sistem Pembinaan Luar Lembaga bagi Narapidana yang Merata dan Berkeadilan Berperspektif pada Tujuan Pemasyarakatan. Jurnal Hukum dan Pembangunan. 45(1), 1-32. doi: 10.21143/jhp.vol45.n1, p. 9

32 Kennedy, Posma Sariguna Johnson.(2017).Hubungan Persepsi Potensi Korupsi, Daya Saing dan Kemudahan Berusaha serta Dampaknya pada Pertumbuhan Ekonomi Daerah: Analisa Data Dari Survei Persepsi Korupsi. Jurnal Ikraith-Humaniora. 1(2), 53-60. doi: - Available from: https://journals.upi-yai.ac.id/index.php/ikraith-humaniora/article/view/151/73, p. 55-56 
Akhirnya, dari faktor struktural dimana korupsi dilakukan juga memiliki pengaruh. Treisman ${ }^{33}$ menyebut faktor struktural ini terkait erat dengan tingkatan pendapatan atau kondisi ekonomi yang tidak berimbang. Senada dengan hal tersebut, Kumara Dewi34 memberikan analisis adanya keterkaitan suatu kekuasaan atau relasi yang terbentuk dengan dilakukannya perilaku korupsi. Kekuasaan (power ${ }^{35}$ dan kesempatan (chance/opportunity) ${ }^{36}$ justru dipandang sarana untuk melakukan korupsi. Perlu diingat bahwa Lapas sebenarnya diinstruksikan sebagai lembaga yang bertugas untuk membina supaya narapidana ketika sudah selesai menjalani masa hukumannya dapat diterima kembali oleh masyarakat. Lebih lanjut, Konsiderans huruf c UU No. 12 Tahun 1995 tentang Pemasyarakatan (UU Pemasyarakatan) menegaskan tujuan pemasyarakatan supaya narapidana dibina untuk menyadari kesalahannya, memperbaiki diri, dan tidak mengulangi tindak pidana yang dilakukannya sehingga dapat diterima dan berperan aktif dalam masyarakat, Faktor struktural tampak jelas dalam hal ini bahwa pemasyarakatan merupakan bentuk tanggungjawab masyarakat yang dilakukan oleh Pemerintah untuk mengembalikan individu yang melanggar kembali kepada skala nilai masyarakat yang ditentukan. Penekanan faktor struktural lainnya juga tampak dalam pemberlakuan UUPTPK yang menyoroti ruang lingkup perbuatan korupsi sebagai perbuatan yang dilarang oleh Undang-Undang maupun hukum (melawan hukum) untuk dilakukan dengan menyalahgunakan kewenangan yang ada pada dirinya untuk menguntungkan diri sendiri37 dan sebaliknya merugikan keuangan negara.

Hal yang dimaksudkan terkait dengan kedudukan WH sebagai Kepala Lapas Sukamiskin mengetahui kondisi yang memudahkannya melakukan suap mengingat semua oknum yang terlibat berada dalam pengawasan dan kekuasaannya. Persis seperti dijelaskan oleh Durahman ${ }^{38}$ bahwa para oknum satu dan lainnnya saling menutupi dan menjaga diri untuk tidak membuka tindakan suap ini dengan menerapkan kebijakan internal tertentu. Mantan Kepala Lapas Sukamiskin yang melakukan korupsi juga terkena UUPTPK ini sehingga ia dianggap mengetahui keberlakuan, larangan perbuatan dan sanksi yang akan dikenakan kepadanya. Pandangan sobural yang dimiliki oleh WH pelaku mantan Kepala Lapas Sukamiskin juga ditinjau dari nilai sosial, nilai budaya dan faktor struktual yang dipahami. Berdasarkan kasus tersbeut, WH, mantan Kepala Lapas Sukamiskin telah mengakui bahwa dirinya menerima suap untuk memberikan fasilitas mewah ke narapidana kasus korupsi. WH mengatakan bahwa

33 Treisman, D.(2000). The Cause of Corruption: A Cross-National Study. Journal of Public Economics, 76(3), 399-457. doi: -, Available from: https:// www.amherst.edu/media/view/131389/original/Treisman2000.pdf, p. 440-445

34 Dewi, Cokorde Istri Kumara.(2018). Struktur dan Agensi: Analisa Sosial terhadap Perilaku Korupsi. Jurnal Dharmasmrti. 9(2),59-65 .doi: $10.32795 /$ ds.v9i2.147, p. 61-63

35 Othman, Zaleha. Shafie, Rohami. Fathilatul, Zakimi Abdul. Hamid, Loc.Cit.

36 Niasa, La, et.al.(2016). Corruption Eradication In The perspective of Criminology. International Journal of Scientific \& technology Research. 5 (7), 124-127. doi: - Available from: http://www.ijstr.org/final-print/july2016/Corruption-Eradication-In-The-Perspective-OfCriminology.pdf, p. 126

37 Juliani, Henny.(2019).Akibat Hukum Penyalahgunaan Wewenang Administrasi Pejabat Pemerintahan yang Menimbulkan Kerugian Keuangan Negara. Administrative Law \& Governance Journal, 2(4),598-614., DOI: https:// doi.org/10.14710/alj.v2i4.598-614, p. 603-606

38 Durahman, Dani.(2016). Penerapan Sanksi bagi Penegak Hukum Penerima Suap dalam Proses Peradilan Pidana. Jurnal Lex Specialist, 24, 51-69, p. 66-67. 
"saya terima dan saya mengakui salah dalam mengelola lapas ini." 39 Dakwaan Jaksa Penuntut Umum menjelaskan bahwa terdapat transaksi suap antara WH dan narapidana kasus korupsi FD sebagai berikut:

Tabel.1 Suap Narapidana FD dan Fasilitas yang diberikan WH

\begin{tabular}{|c|c|}
\hline Suap Narapidana FD & Fasilitas yang diberikan $\mathrm{WH}$ \\
\hline $\begin{array}{l}\text { Mobil Mitsubishi Triton Hitam senilai } \\
\text { Rp } 427 \text { Juta }\end{array}$ & $\begin{array}{l}\text { Menempati ruan tahanan No. } 11 \text { Blok } \\
\text { Timur Atas }\end{array}$ \\
\hline $\begin{array}{l}\text { Uang senilai Rp 4,5 Juta dan Rp 15 Juta } \\
\text { pada Mei } 2018\end{array}$ & $\begin{array}{l}\text { Memiliki tahanan pendamping yang } \\
\text { dibayar untuk cleaning service dan } \\
\text { kurir makanan }\end{array}$ \\
\hline Sepatu buatan Cina & Menggunakan telpon seluler pribadi \\
\hline Uang senilai Rp 20 Juta pada Juni 2018 & $\begin{array}{l}\text { Membangun ruagan khusus untuk } \\
\text { berhubungan badan dengan istri saat } \\
\text { kunjungan }\end{array}$ \\
\hline Sandal merek Kenzo & $\begin{array}{l}\text { Izin cek kesehatan rutin ke Rumah } \\
\text { Sakit Hermina Arcamanik dan Rumah } \\
\text { Sakit Hermina Pasteur setiap Kamis } \\
\text { setelah itu kembali ke Lapas pada hari } \\
\text { Senin }\end{array}$ \\
\hline \multicolumn{2}{|l|}{ Tas merek Louis Vuitton } \\
\hline Suap Narapidana CW & Fasilitas yang diberikan WH \\
\hline Uang Rp 2,73 juta (April 2018) & $\begin{array}{l}\text { izin luar biasa untuk kepentingan } \\
\text { keluarga yang digunakan untuk } \\
\text { menginap di Hotel Hilton Bandung }\end{array}$ \\
\hline Uang Rp 26, 2 juta (Mei 2018) & $\begin{array}{l}\text { Izin cek kesehatan ke Rumah Sakit } \\
\text { Roseladan Rumah Sakit Arcamanik } \\
\text { digunakan untuk menginap di } \\
\text { kediaman pribadi dan hotel }\end{array}$ \\
\hline \multicolumn{2}{|l|}{ Uang Rp 33 Juta (Juni 2018) } \\
\hline Suap Narapidana FAI & Fasilitas yang diberikan $\mathrm{WH}$ \\
\hline Uang Rp 10 Juta (Maret 2018) & $\begin{array}{l}\text { Izin cek kesehatan ke Rumah Sakit } \\
\text { Dustira Cimahi digunakan untuk } \\
\text { menginap di rumah pribadi }\end{array}$ \\
\hline Uang Rp 35 juta (April 2018) & $\begin{array}{l}\text { Izin luar biasa untuk kepentingan } \\
\text { keluarga tanggal } 30 \text { April } 2018 \text { tetapi } \\
\text { baru kembali pada } 4 \text { Mei } 2018\end{array}$ \\
\hline $\begin{array}{l}\text { Uang Rp } 20 \text { Juta dan Rp } 6 \text { Ju } \\
\text { dan Juni 2018) }\end{array}$ & \\
\hline
\end{tabular}

39 Hantoro, Juli, Ed. Eks Kepala Lapas Sukamiskin Akui Terima Suap dari Napi Korupsi. Available from: $\quad$ https://nasional.tempo.co/read/1114772/eks-kepala-lapas-sukamiskin-akui-terima-suap-darinapi-korupsi/fullEview $=o k, 7$ Agustus 2018. (Diiakses 29 April 2019) 
Berdasarkan perbuatan yang dilakukan oleh WH tampak bahwa ia memandang pemenuhan keinginan diri menjadi hal yang diutamakan oleh dirinya. Nilai sosial yang diharapkan ada dalam dirinya untuk mendukung kehidupan bersama dengan melakukan pembinaan Narapidana kasus korupsi tidak dilakukan. Perbuatan WH justru mengakibatkan narapidana tidak menyesali perbuatannya bahkan cenderung mengulangi perbuatan korupsi sebagaimana tampak dengan melakukan tindakan suap. Nilai budaya pun sebenarnya WH justru hanya mengutamakan kemanusiaan yang berorientasi pada diri sendiri. WH justru menganggap jika ia memberikan fasilitas dan izin kepada narapidana kasus korupsi dengan imbalan tertentu merupakan cara khusus bagi dia untuk mendapatkan keuntungan di luar gaji yang diperolehnya. Berdasarkan kondisi tersebut WH gagal dalam memahami nilai sosial maupun nilai budaya yang diemban oleh masyarakat Indonesia. Faktor struktural, dalam hal ini berperan sangat besar tampak dari kekuasaan ekononmi narapidana kasus korupsi sebagai mantan pejabat negara. Kepemilikan harta kekayaan menjadi keunggulan yang bisa dimanfaatkan oleh narapidana kasus korupsi untuk memberikan tekanan psikologis pada WH untuk menuruti kemauan narapidana. WH di sisi lain juga memiliki kekuasaan untuk melakukan pengaturan khusus dan memberikan izin bagi narapidana. Kewenangan ini merupakan tanggung jawab mutlak dari Kepala Lapas, alhasil kewenanangan ini rawan disalahgunakan. Korupsi di Lembaga Pemasyarakatan pun semakin mudah dilakukan.

\subsection{Tantangan Pencegahan Korupsi di Lembaga Pemasyarakatan a la Sobural}

Upaya Pencegahan pada dasarnya merupakan bagian dari semangat pemberantasan korupsi. Sebagai upaya pencegahan korupsi di Lapas perlu menyimak hasil analisis pendekatan kasus Korupsi di Lapas Sukamiskin. Jika diamati pendekatan Sobural terhadap masyarakat tempat dilakukannya perbuatan sama sekali tidak mendukung korupsi baik dari sisi nilai sosial, nilai budaya maupun faktor struktural. Hal yang penting untuk diperhatikan yaitu pemahaman nilai sosial, nilai budaya dan faktor struktural dari pelaku yang dalam hal ini Kepala Lapas. Pelaku sama sekali tidak memahami nilai sosial dalam hal pengutamaan kemanusiaan yang adil dan beradab dalam pemasyarakatan. Begitu pula halnya dengan nilai budaya yang mengedapankan pemenuhan kebutuhan diri dengan menghalalkan segala macam cara. Berdasarkan kondisi tersebut langkah preventif seperti penghayatan nilai kemanusiaan dalam pemasyarakatan dan perubahan sikap mental antikorupsi. Penghayatan nilai kemanusiaan ini tidak hanya dilakukan dalam bentuk pelatihan ataupun seminar akan tetapi dilakukan dalam bentuk komunitas yang secara rutin berinteraksi sehingga mampu memberikan dampak yang positif bagi perubahan penghayatan Pancasila. Perubahan sikap mental pada dasarnya merupakan tanggungjawab pribadi individu akan tetapi masyarakat dapat memberikan kontribusi secara nyata dengan tidak memberikan suap ataupun kemudahan yang membuat pelaku korupsi melakukan penyalahgunaan wewenang untuk kepentingan dirinya.

Pencegahan korupsi dari sisi faktor strukrural memegang peran penting dalam menciptakan sistem kerja yang bersih dari korupsi. Mengingat Kepala Lapas memegang kewenangan absolut atas pengelolaan Lapasnya maka diperlukan sebuah badan pengawas yang memainkan fungsi check and balances. Setiap tindakan dan kebijakan Lapas harus mendapatkan pengawasan dari badan pengawas ini sehingga kebijakan pun terhindar dari penyalahgunaan kewenangan. Hal lain yang tidak kalah penting terkait dengan keberadaan Lapas Khusus Narapidana Kasus Korupsi. Pengkhususan 
Narapidana kasus Korupsi sendiri menunjukkan perlakuan istimewa terhadap narapidana kasus korupsi dengan narapidana lainnya. Sebagaimana ditekankan dalam UU Pemasyarakatan, upaya pemasyarakatan pada dasarnya tidak mengenal pembedaan perlakuan antara narapidana satu dengan lainnya. Hal tersebut sudah seharusnya berlaku hal yang sama dengan narapidana kasus korupsi. Langkah tersebut dapat membuat narapidana kasus korupsi mengaktualisasi diri sesuai dengan nilai masyarakat bukan sebaliknya.

\section{Kesimpulan}

Pendekatan Sobural menjadi pisau analisa kriminologis yang membedah causa kejahatan secara utuh, baik diri pelaku maupun masyarakat. Keunggulan Sobural sebagai sebuah pendekatan memberikan cara bagi penegak hukum, terutama hakim untuk memahami perbuatan korupsi di Lapas secara utuh. Jika pada umumnya Hakim hanya terpaku pada pemahaman akan ada atau tidaknya pemenuhan unsur atas ketentuan UU PTPK, pendekatan sobural memainkan peran penting dalam menghadirkan pemahaman kriminologis seseorang melakukan kejahatan dan kondisi masyarakat dilakukannya perbuatan. Pendekatan Sobural tidak pernah meninggalkan pelaku menanggung beban pertanggungjawaban seorang diri melainkan menggapai pemahaman lebih luas akan peran masyarakat yang perlu di evaluasi. Potret kriminologis korupsi di Lapas Sukamiskin tampak bahwa pemahaman akan kondisi masyarakat sudah baik dalam memahami korupsi sebagai perbuatan yang tercela. Hanya saja dari sisi pelaku, ia mengalami kegagalan dalam memahami kemanusiaan dalam kehidupan bersama sehingga lebih memilih langkah menghalalkan segala macam cara untuk memuaskan keinginan pribadinya. Kondisi tersebut semakin diperparah dengan kewenangan mutlak yang dimiliki untuk pengelolaan Lapas tanpa ada pengawasan. Berdasarkan hal tersebut upaya pencegahan dapat dilakukan dengan memberikan solusi praktis terhadap pejabat pemerintah dengan memberikan penghayatan kemanusiaan yang adil dan beradab dan perubahan sikap mental. Kewenangan Kepala Lapas pun harus diimbangi dengan keberadaan badan pengawas demi sistem check and balances.

\section{Daftar Pustaka}

\section{$\underline{\text { Buku }}$}

Garner, Bryan A., ed. (2004). Black's Law Dictinionary, Eighth Edition, London: West Thomson.

PSP UGM Yogyakarta \& TIFA.(2016). Pancasila sebagai Dasar Negara: Kursus Presiden Soekarno tentang Pancasila. Jakarta: Aditya Media \& Pusat Studi Pancasila (PSP) UGM dan Yayasan TIFA.

Sahetapy., J.E., (1983). Pisau Analisa Kriminologi: Pidato Pengukuhan Guru Besar Fakultas Hukum Universitas Airlangga, 30 Juli 1983, Surabaya: Fakultas Hukum Universitas Airlangga. Aditya Bhakti.

, Sahetapy, Elfina L., ed.(2005) Pisau Analisis Kriminologi. Bandung: Citra

Santoso, Topo., \& Zulfa, Eva Achjani., (2001). Kriminologi. Jakarta: Rajawali Press.

\section{Jurnal}


Aditya, Z. F. (2019). Romantisme Sistem Hukum Di Indonesia: Kajian Atas Konstribusi Hukum Adat Dan Hukum Islam Terhadap Pembangunan Hukum Di Indonesia. Jurnal Rechts Vinding: Media Pembinaan Hukum Nasional, 8(1) 37-54. DOI: http://dx.doi.org/10.33331/rechtsvinding.v8i1.305.

Bernardi, Richard A., \& Hayashi, Ikki., (2013).The Association between Bribery and Unethical Actions: An Asian Perspective. European Journal of Business and Innovation Research. 1(2), 70-84.

Dewi, Cokorde Istri Kumara., (2018). Struktur dan Agensi: Analisa Sosial terhadap Perilaku Korupsi. Jurnal Dharmasmrti. 9(2),59-65 .doi: 10.32795/ds.v9i2.147

Djanggih, H., \& Qamar, N. (2018). Penerapan Teori-Teori Kriminologi dalam Penanggulangan Kejahatan Siber (Cyber Crime). Pandecta Research Law Journal, 13(1), 10-23. doi: 10.15294/ pandecta.v13i1.14020.

Durahman, Dani.,(2016). Penerapan Sanksi bagi Penegak Hukum Penerima Suap dalam Proses Peradilan Pidana. Jurnal Lex Specialist, 24, 51-69.

Fonseca, Xavier., et.al.(2019). Social Cohesion revisited: a new definition and characterize it. Journal Innovation: The European Journal of Social Science Research. 32(2), 231-253. doi: 10.1080/13511610.2018.1497480

Gorsira, Madelijne., Denkers, Adriaan., Huisman, Wim.,(2018). Both Sides of the Coin: Motives for Corruption Among Public Officials and Business Employees. Journal of Business Ethics.151, 179-194. doi: 10.1007/s10551-016-3219-2

Gumerov, A. Timur., et. al. (2016). Concept and Criminological Characteristics of Corruption on Criminality. Journal of Legal, Ethical dan Regulatory Issues, 19 (Special Issues), 82-87.

Haryadi, Slamet.,.(2015). Reinterpretasi Tindak Pidana Korups Suap oleh Penegak Hukum dalam Perspektif Hukum Islam. Jurnal Al-'adalah 12(3), 541-552. doi: 10.24042/adalah.v12i1.233.

Henderson, J.Vernon., \& Kuncoro, Ari., (2011). Corruption and Local Democratization in Indonesia: the Role of Islamic Parties. Journal Development Economics. 94(2), 164180. doi: 10.1016/j.jdeveco.2010.01.007.

lbanese, Jay S. \& Artello, Kristine., (2019). The Behavior of Corruption: An Empirical Typology of Public Corruption by Objectibe \& Method. Criminology, Criminal Justice, Law \& Society. 20( 1), 1-12. doi: - Availabe from ccjls.scholasticahq.com/ 7735-the-behavior-of-corruption-an-empirical-typology-of-public-corruption-byobjective-method.

Ifrani.(2017). Tindak Pidana Korupsi sebagai Kejahatan Luar Biasa. Jurnal Al'adl. IX (3), 319-336. doi: 10.31602/al-adl.v9i3.1047.

Isra, Saldi., et.al.(2017). Obstruction of Justice in the Effort to Eradicate Corruption in Indonesia. Internasional Journal of Law Crime and Justice, 51 December, 72-83. doi: 10.1016/j.ijlcj.2017.07.001.

Juliani, Henny.,(2019).Akibat Hukum Penyalahgunaan Wewenang Administrasi Pejabat Pemerintahan yang Menimbulkan Kerugian Keuangan Negara. Administrative Law $\mathcal{E}$ Governance Journal, 2(4),598-614.

Kennedy, Posma Sariguna Johnson., (2017).Hubungan Persepsi Potensi Korupsi, Daya Saing dan Kemudahan Berusaha serta Dampaknya pada Pertumbuhan Ekonomi Daerah: Analisa Data Dari Survei Persepsi Korupsi. Jurnal Ikraith-Humaniora. 1(2), 53-60. doi: - Available from: https://journals.upi-yai.ac.id/index.php/ikraithhumaniora/article/view/151/73

Lee, Wang-Sheng., \& Guven, Cahit., (2013). Enganging in Corruption: The Influence od Cultural Values and Contagion Effects at the Micro Level", Journal of Economic Psychology, 39, 287-300. doi: 10.1016/j.joep.2013.09.006 
Niasa, La., et.al.(2016). Corruption Eradication In The perspective of Criminology. International Journal of Scientific \& technology Research. 5 (7), 124-127. doi: - Available from: http://www.ijstr.org/final-print/july2016/Corruption-Eradication-InThe-Perspective-Of-Criminology.pdf

Prabowo, Hendi Yogi., (2014). To be corrupt or not to be corrupt: Understanding the behavioral side of corruption in Indonesia. Journal of Money Laundering Control. 17(3), 306-326. doi:10.1108/JMLC-11-2013-0045.

Othman, Zaleha., Rohami Shafie, Fathilatul Zakimi Abdul Hamid. (2014). CorruptionWhy do they do it? Procedia-Social and Behavioral Studies 164, 248-257. doi:10.1016/j.sbspro.2014.11.074.

Susanti, Dyah Octorina., \& Efendi, A'an., (2019). Memahami Teks Undang-Undang dengan Metode Interpretasi Eksegetikal. Jurnal Kertha Patrik., 41(2), p.141-154. doi: 10.24843/KP.2019.v41.i02.p05.

Treisman, D. (2000). The Cause of Corruption: A Cross-National Study. Journal of Public Economics, 76(3), 399-457.

Wardhani, Noeke Sri., Hartati, Sri., \& Rahmasari, Helda.,.(2015). Sistem Pembinaan Luar Lembaga bagi Narapidana yang Merata dan Berkeadilan Berperspektif pada Tujuan Pemasyarakatan. Jurnal Hukum dan Pembangunan. 45(1), 1-32. doi: 10.21143/jhp.vol45.n1.

\section{Artikel dari Sumber Online}

Hantoro, Juli., Ed. Eks Kepala Lapas Sukamiskin Akui Terima Suap dari Napi Korupsi. Available from: https://nasional.tempo.co/read/1114772/eks-kepala-lapas-sukamiskinakui-terima-suap-dari-napi-korupsi/fullEview=ok, 7 Agustus 2018. (Diiakses 29 April 2019)

U4 Aexpert Answer, "Causes of Corruption in Indonesia", Anti-Corruption Resource Centre, Available from: https://www.u4.no/publications/causes-of-corruptionin-indonesia. (Diakses 19 Mei 2020)

\section{Artikel Surat Kabar}

Litbang Kompas, “Budaya Suap Mencengkeram Lapas”, Harian Kompas 30 Juli 2018 